\title{
FIRST RECORD OF THE PARASITIC COPEPOD, LERNANTHROPUS INDICUS (CRUSTACEA: LERNANTHROPIDAE) ON CARANGOIDES BAJAD FROM THE RED SEA, EGYPT
}

\author{
SALWA Z. A. ARAFA ${ }^{1}$ AND SHEREEN FAHMY ${ }^{2^{*}}$
}

Departments of Zoology, Faculties of Science, Zagazig University ${ }^{1}$, and Damietta University ${ }^{2}$, Egypt ( ${ }^{*}$ Correspondence: shereenfahmy80@yahoo.com)

\begin{abstract}
The present work investigated Lernanthropidae copepod genus Lernanthropus based on adult female specimens removed from the gills of orange spotted travally Carangoides bajad, a commercially important teleost fish species of the Red Sea, Egypt in during the period from April 2015 to March 2016. A total of 82 C. bajad (Local name: Bayad) were examined, 35 specimens were identified as Lernanthropus indicus. Lernanthropus indicus is an important pest of economically valuable importance fishes in seawater and, therefore, can cause severe damage to the host tissues. The present work represents the first record for the presence of this parasite in $C$. bajad fish as a new host in Red Sea water. The presented results were investigated by scanning electron microscopy. Female body surface ventrally ornamented with patches of setules and elongated with long egg sacs. Cephalothorax with dorsal shield slightly is narrower anteriorly. SEM showed that the $2^{\text {nd }}$ antenna of Lernanthropus is characteristically prehensile and uncinate and thus provides the main force for the attachment to the host tissue.
\end{abstract}

Key words: Carangoides bajad; Lernanthropus indicus; parasitic copepods; marine fish.

\section{Introduction}

Fish play an important role in economy. Mortality of fishes occurs due to heavy infestation of the parasites. Keeping in view the increasing importance of fish as rich source of protein diet (Bhure et al, 2016), Carangoides bajad Forsskal, 1775 (Carangoidae) was a demersal carangid fish, widely distributed in the Red Sea. It is an important commercial fish along the Red Sea (AlZubaidy, 2010). Parasitic copepods are commonly found in cultured and wild marine fishes (Jones et al, 2012; Ramesh-kumar and Ravichandran 2013). Custacean parasites are considered an important lim-iting factor in the development of intensified fish culture (Osman et al, 2014). Among crustaceans, copepods are dominant. They are species group of metazoan ectoparasites of marine fishes. Lernanthropidae is a large family of siphonostomatid copepods conta-ining over 150 species. They are exclusively parasitic on gill filaments of marine teleosts, and use their prehensile antennae and maxillipeds to attach tenaciously to a hosts gill filaments (Kabata, 1979). The second antenna of the Lernanthropus is characteristically prehen- sile and uncinate and provides the main force for attachment to the host tissue. The assisting action in the process of attachment is thought to be achieved by first maxillae, second maxillae, maxillipeds and the first four thoracic legs and thus, can cause severe damage to the host tissues (Fahmy, 2015).

Lernanthropus is the most common genus of parasitic copepod, among more than 100 described species. All species are parasitic on the gills of marine teleosts, most of them inhabiting warmer waters. Some species of Lernanthropus are strictly specific, however many are parasitic on several species of fish belonging to one genus, or several genera of one family (Kabata, 1979). Parasitic fauna of orange spotted trevally Carangoides baj$a d$, from Egypt are poorly known. Now a days, there were no data on the crustacean parasites of this fish species.

Through April 2015 to March 2016, the study was achieved to document parasitic copepods of fishes in the Red Sea coastal waters, Egypt. A total of 82 specimens of $C$. bajad fish were examined. This work proved for the first time the parasitic copepod infection from C. bajad fish in the Egypt's Red Sea Coasts. 


\section{Material and Methods}

Lernanthreopides were isolated from the teleost fish species Carangoides bajad. A total of 82 specimens were collected from the Red Sea coast, during the period from April 2015 to March 2016. Specimens of $L$. indicus were studied using scanning electron microscopy. Body surface (skin, fins) and gills of the fish were examined. Gill arches were carefully removed and studied in a fresh condition. Copepods were identified based on morphological features (Pillai, 1967; Kabata, 1979). The crustaceans were removed alive from their hosts, washed repeatedly with seawater to free them from mucus, fixed in cold $\left(4^{\circ} \mathrm{C}\right) 2.5 \%$ glutaraldehyde in $0.1 \mathrm{M}$ sodium cacodylate buffer at $\mathrm{pH}$ 7.2, dehydrated in a graded acetone series $(30 \%, 50 \%, 75 \%, 90 \%, \& 100 \%)$, critical-point-dried, and sputter-coated with gold/ palladium. Then, they were mounted on metal stubs and coated with a gold film by sputtering, before being examined under JEOL JSM-6510LV SEM operated at an accelerating voltage of $30 \mathrm{kV}$ in the Electronic Microscopy Unit, Mansoura University.

\section{Results}

Females of Lernanthropus indicus were collected from the gills of Carangoides bajad from Egypt Suiz Gulf Red Sea coastal waters for the first time. All parasites were firmly attached to the gill arches. Male: Not collected. Morphological detail was seen with the aid of SEM. Adult female copepods were attached to the gill arches by their second antennae and third legs. Female body is large, divided into cephalothorax and trunk. Cephalothorax is nearly square in shape and with narrow antennal region (Figs. $1 a \& b, 3 b)$. Cephalic shield presented to first pedigerous segment; slightly longer than broad, subcircular with narrower posterior margin (Figs. 1a, 3a). Cephalothorax with four pairs of cephalic appendages (antennules, antennae, maxillules, \& maxillae), and three pairs of thoracic appendages; maxillipeds, and four pair of legs. Trunk consists of posterior part of the thorax (genital comp- lex), abdomen and dorsal plate (Figs. 1a, b $\& 3 a)$. By SEM, antenna, maxillae and maxilliped of $L$. indicus were grasping or tightly holded to host's gill arch (Figs. 1a, b \& 3b). Second maxilla (Figs. 1b \& 3b) uniramous, brachiform and two-segmented; proxymal segment (lacertus) large elongate unarmed and second segment (brachium) slender. Maxillipeds (Figs. 1a, b, c \& 3b) 2-segmented; corpus stout unarmed, subchela armed with single subterminal seta and claw apically directed with longitudinal ridges.

Mouth tube (cone) (Figs. 1a, b, e \& 3b) conical with tip directed posteriorly, situated between the maxillules and maxillae; labrum shorter than labium, blunt ending with some integumental folds on frons. Labrum carries two prominently bifid tube-like buccal stylets (Fig. 1e). Dorsal shield of genital complex in female expanded posteriorly and dorsally forming a sac (dorsal plate) with a supporting dorsal layer completely covering the abdomen (Fig. 1d \& 3a). First thoracic leg with protopod protruded out into a process that carries an outer seta at its base. Second thoracic leg more reduced than $1^{\text {st }}$ leg, with inconspicuous protopod and weakly armed exopod, folded lamella splayed ventrally at poster lateral corners of trunk (Fig. 1b). Third thoracic leg: large, foliaceous and slightly folded along longitudinal axis (Fig. 3a). Fourth thoracic leg (Fig.1d \& 3a) originated anteroventrally to abdominal base bifurcate, lobes lanceolate, more than $75 \%$ protruded posteriorly of dorsal plate.

Integumentary structures: SEM provided useful information on integument structures of $L$. indicus. Several types of presumed sensory structures and cuticular outgrowths were identified on its body surface. Tegumental structures such as spines, setules, denticles, teeth and rows with various forms and sizes were seen on body surface and appendages (Figs. 2a, b). Ornamented papillae bearing cilium found on body surface, observed near the first and second leg. Every cilium branched out (Fig. 2c). Pores were also observed on tegument (Figs. 2b, c, d). 
Besides, spherical papillae on cephalothorax surface (Figs. 4a, b, c)

\section{Discussion}

Parasitic copepods are common in cultured and wild marine fishes (Jones et al, 2012; Rameshkumar and Ravichandran 2013). With the expansion of marine aquaculture, the importance of parasitic copepods as disease agents was raised (Johnson et al, 2004). The family Lernanthropidae (Yamaguti, 1963) contains eight genera including the largest genus Lernanthropus (Boxshall, 2011). Lernanthropus is of lernanthropids comprised 111 species. Lernanthrophus sp. was isolated from gills of Trachurus indicus and Nemipterus Japonicu that agreed with Purivirojkul and Areechon (2008), Antonelli et al. (2012) and Khidr et al. (2014) who isolated the same genus from marine fish species. Morphological characters \& measurements were nearly similar. The genus is characterized by having a large dorsal plate on posterior border of the trunk.

Lernanthropus indicus recorded from the carangids in the Indian waters are probably synonymous with L. giganteus and showed that this species shows close resemblance to parasites of carangids such as L. giganteus and L. koenigii. But, L. indicus with distinct difference in appendages (Krishna, 1985). Indian L. indicus isolated from Caranx sansun was similar with L. nemipteri from Nemi forcousus Jayasree \& Pillai except the cephalothorax groove of the later species.

The current study, by SEM showed more morphological data of $L$. indicus female that agreed with Al-Ataby et al. (2013) who reported L. indicus from carangid fishes, Megalaspis cordyla and Carangoides malabricus in the Arabian Gulf. The present $L$. indicus was recorded from carangid fishes, Carangoides bajad in the Red Sea.

\section{Conclusion}

The present work is the first record for this parasite of C. bajad fish in Egyptian Red Sea Coast.

\section{References}

Al-Ataby, FH, Al-Niaeem, KS, Al-Azizz, SA, 2013: A new record of the parasitic copepod,
Lernanthropus indicus (Pillai, 1967) (Copepoda: Lernanthropidae) from carangid fishes in northwest Arabian Gulf, Iraq. Egypt. J. Exp. Biol. (Zool.), 8, 2:175-9.

Al-Ataby, FHA, 2012: Taxonomical and histopathological study of some carangid fishes parasites in Basrah Province/Iraq. In Press

Al-Zubaidy, A, 2010: First Record of Lecithochirium sp. (Digenea: Hemiuridae) in the marine fish Carangoides bajad from the Red Sea Coast of Yemen. JKAU: Mar. Sci. 21:85-94.

Antonelli, L, 2012: Lernanthropus kroyeri (Van Beneden and Hesse 1851) parasitic Copepoda (Siphonostomatoidae, Lernanthropidae) of European cultured sea bass Dicentrarchus labrax (Linnaeus 1758) from Corsica: ecological and morphological study, Parasitol. Res. 110:1959-68.

Bhurea, D. Nanwareb, S. Jadhavc, A, 2016: Prevalence and diversity of cestode parasites of freshwater fishes of genus Channa Scopoli, 1777. Wld. Sci. News 33:15-26.

Boxshall, G, 2011: Lernanthropidae. In TC Walter, G Boxshall, eds. World Copepoda database. At http://www.marinespecies.org/copepoda/ aphia.php? $\mathrm{p}=$ taxdetails \& id=135526.

Fahmy, Sh, 2015: Ultrastructural features of some integumental structural of Lernanthropus kroyeri Van Beneden parasitic copepoda (Siphonostomatoidae, Lernanthropidae). Sci. J. Damietta Fac. of Sci. 5, 1:110-6.

Johnson, S. Treasurer, J. Bravo, S, Nagasava, K, Kabata, Z, 2004: A review of the impact of parasitic copepods on marine aquaculture. Zool. Stud. 43, 2:229-43.

Jones, S, Prosperi-Porta, G, Kim, E, 2012: The diversity of microsporidia in parasitic copepods (Caligidae: Siphonostomatoida) in the Northeast Pacific Ocean with description of Facilispora margolisi n. g., n. sp. and a new family Facilisporidae n. fam. J. Eukaryot. Microbiol. 59, 3:206-17.

Kabata, Z, 1979: Parasitic copepoda of British fishes. Ray Soc., London, UK, 152:468.

Khamees, N, Mhaisen, F, Ali, A, 2015: Checklists of crustaceans of freshwater and marine fishes of Basrah Province, Iraq, Mesopot. J. Mar. Sci. 30, 1:1-32.

Khidr, A, Ola, A, Said, A, Ghoneim, A, Fahmy, Sh, 2014: Structural and functional observations on the appendages of gill parasite, Lernanthropus Kroyeri (Copepoda: Lernanthropidae) infesting the Sea Bass Dicentrarchus labrax. Nature Sci. 12, 2:101-7. 
Krishna, PN, 1985: The fauna of India copepod parasites of marine fishes. The Technical \& General Press, Calcutta and Published by the Director, Zoological Survey of India, Calcutta.

Osman, H, Hassan, M, El- Refaey, A, 2014: Studies on Sarcotaces sp. (Copepoda, Philichthyidae) Infestation (Black Bag Disease) among some marine fish species of Arabian Gulf, Saudi Arabia. Wld. Appl. Sci. J. 32, 9:1780-8.

Pillai, NK. (1967): Copepods parasitic on Indian marine fishes: A review proceedings of symp- osium on crustacean. Cochin 5:1556-680.

Purivirojkul, W, Areechon, N, 2008: Survey of parasitic copepods in marine fishes from the Gulf of Thailand, Chon Buri province. Proc. $46^{\text {th }}$ Kasetsart Uni. Ann. Conf., Bangkok, Thailand.

Rameshkumar, G, Ravichandran, S, 2013: Lernaeenicus sprattae (Crustacea: Copepoda) on Hemiramphus far. Mid. East J. Sci. Res. 13, 2: 183-6.

Yamaguti, S, 1963: Parasitic Copepoda and Branchiura of fishes. Intersci. Publ. N.Y.

\section{Explanation of figures}

Fig. 1: SEM of female Lernanathropus indicus Pillai, 1967. (a \& b) cephalothorax in ventral view and its appendages, (c) maxilliped, (d) abdomen, (e) mouth cone. A2, $2^{\text {nd }}$ antenna; M1, $1^{\text {st }}$ maxilla; M2, $2^{\text {nd }}$ maxilla; m, maxilliped; ce, cephalothorax; cs, cephalic shield; mc, mouth cone; s, stylet L1, $1^{\text {st }}$ thoracic leg; L2, $2^{\text {nd }}$ thoracic leg; L4, $4^{\text {th }}$ thoracic leg; a, abdomen and dp, dorsal plate.

Fig. 2: Integument of L. indicus. (a \& b) spinules (spu) of $2^{\text {nd }}$ maxilla, arrowheads (pores), (c \& d) ornamented papillae on dorsal body surface, papillae (pa) and pores (po). Fig. 3: SEM of female L. indicus. a, lateral view; cs, cephalic shield; m, maxilliped; L3, $3^{\text {rd }}$ thoracic leg; $\mathrm{L} 4,4^{\text {th }}$ thoracic leg; and dp, dorsal plate. $\mathrm{b}$, cephalothorax in ventral view and its appendages, $\mathrm{A} 2,2^{\text {nd }}$ antenna; ce, cephalothorax; mc, mouth cone; M1, $1^{\text {st }}$ maxilla; M2, $2^{\text {nd }}$ maxilla and m, maxilliped. Fig. 4: (a, b \& c) spherical papillae on cephalothorax surface of $L$. indicus.

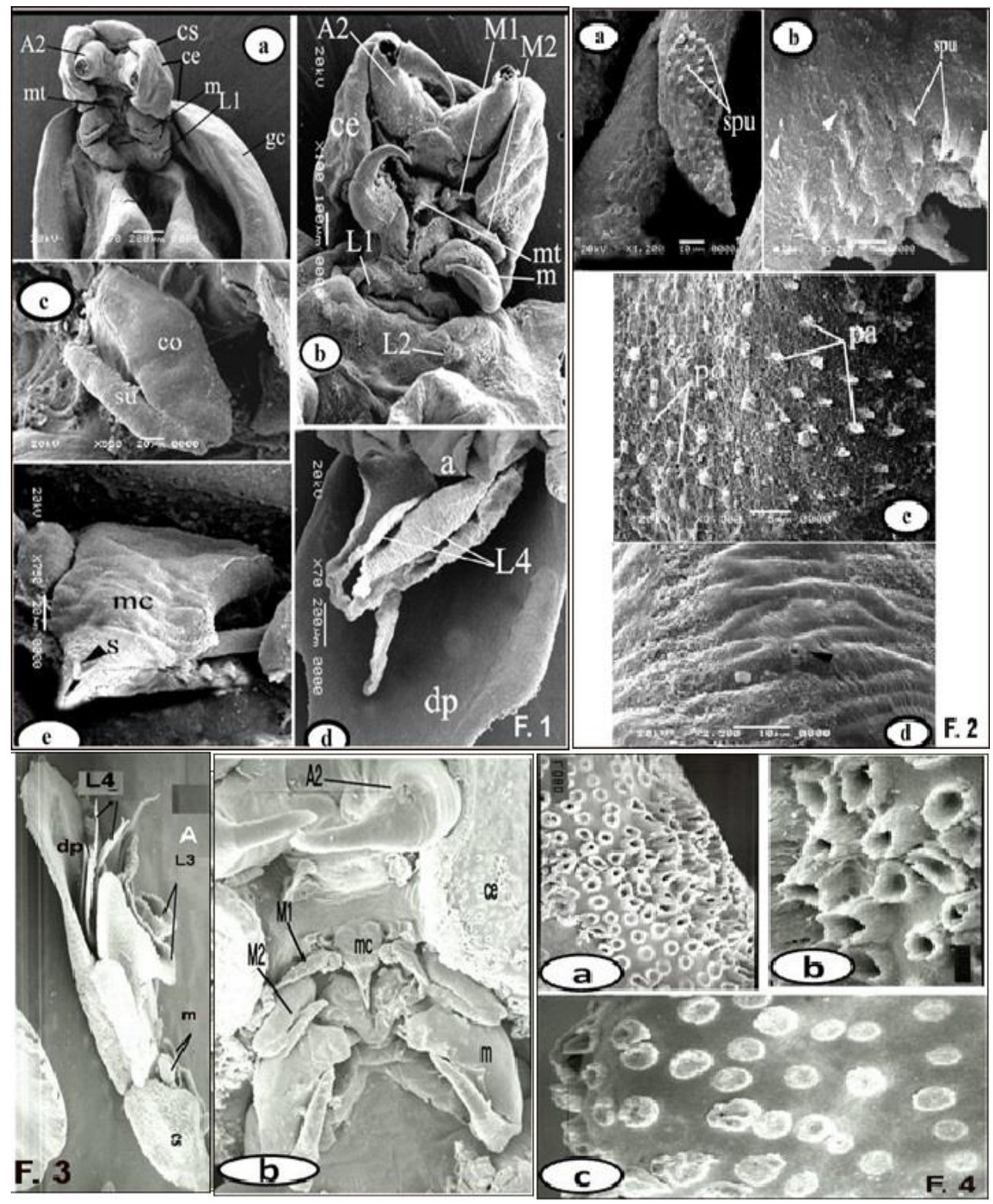

